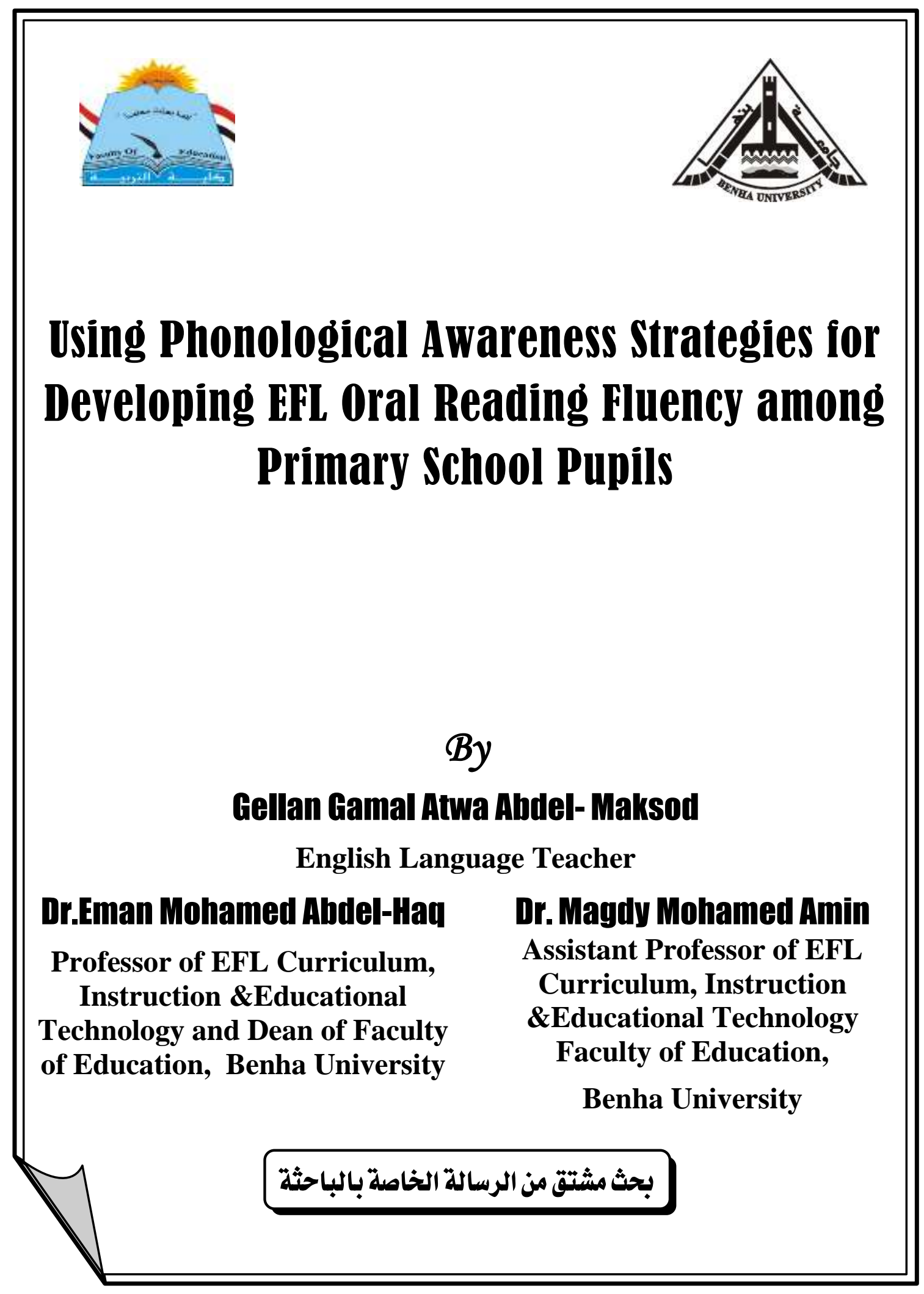




\section{Using Phonological Awareness Strategies for Developing EFL Oral Reading Fluency among Primary School Pupils}

By

Gellan Gamal Atwa Ahdel- Maksod

English Language Teacher

\section{Dr.Eman Mohamed Ahdel-Haq}

Professor of EFL Curriculum, Instruction \&Educational Technology and Dean of Faculty of Education, Benha University
Dr. Magdy Mohamed Amin

Assistant Professor of EFL Curriculum, Instruction \&Educational Technology Faculty of Education, Benha University

\section{Ahstract}

This study aimed at improving some EFL oral reading fluency among 4th year primary school pupils through using some phonological awareness strategies. The participants of the study consisted of 60 4th year primary school pupils in Alshahid Mohamed Abdelrohman Primary School, Menuofia Governorate during the second semester of the school year 2018/2019. The study followed the two-groups (experimental and control) design. The instruments of the study were an EFL oral reading fluency checklist and anEFL oral reading fluency pre-post test. The Pre test was administered to the two groups of 4th year primary school pupils. The experimental group pupils were taught using some phonological awareness strategies (rhyming, alliteration and blending and segmentation) to develop their EFL oral reading fluency. The control group was taught using the traditional strategy. Then, the post-test was administered. Results of the study revealed that the experimental group EFL oral reading fluency (reading simple sentences and answering simple questions) improved significantly compared to the control group as a result of using some phonological awareness strategies. Therefore, it can be concluded that phonological awareness strategies were effective in developing EFL oral reading fluency among 4th year primary school pupils.

Keywords: phonological awareness, oral reading fluency. 


\section{استخدام استراتيجيات الوعي الصوتي لتنمية الطلاقة للقراءة الجهرية}

\section{لالغة الإنجايرية كلغة اجنبية لدى تلاميذ المرحلة الابتدائية}

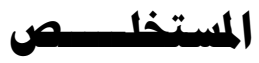

هدفت هذه الدراسة إلى تحسين طلاقة القراءة الجهريـة للغة الإنجليزيـة كلغة أجنبية بين تلاميذ الصفف الرابـع الابتدائي من خـلال استخدام استراتيجيات الوعي الصسوتي. شـارك في الدراسـة • ج تلميذاً في الصف الرابع الابتدائي من مدرسة الثهيد محمد عبد الرحمن الابتدائية

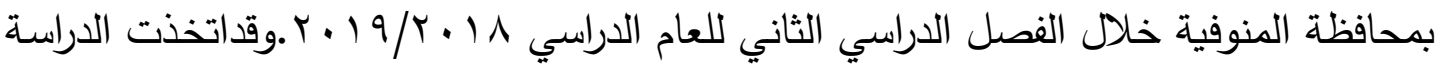
الحاليـة مجموعتين (مجموعـات تجريبية ومجموعـة ضـابطة).وتمثلت ادوات الدراسـة في قائمسة مهارات الطلاقة في اللغـة الإنجليزيـة كلغة أجنبية واختبار الطلاقة للقراءة الجهريـة في اللغـة الإنجليزيـة كلغة أجنبية. تم تطبيق اختبار الطلاقة للقراءة الجهريـة قبليا ثم تم تدريس تلاميذ المجموعـة التجريبية باستخدام استراتيجيات الوعي الصسوتي( القافيـة والدمج والجنـاس) لتطوير طلاقة القراءة الجهريـة للغـة الإنجليزيـة كلغة أجنبية. تم تدريس المجموعـة الضـابطة باستخدام الاستراتيجية التقليدية. بعد ذلك ، ثم إجراء الاختبار البعدي ـ كشفت نتائج الدراسـة أن مهارات الطلاقة في القراءة الجهريـة للغـة الإنجليزيـة قد تحسنت في المجموعة التجريبية بشكل ملحوظ مقارنـة بالمجموعة الضـابطة نتيجة لاستخدام بعض استراتيجيات الوعي الصـوتي. لذلك تؤكد الدراسة الحالية أن استراتيجيات الوعي الصوتي كانت فعالة في تطوير الطلاقة للقراءة الجهريـة للغة الإنجليزية كلغة أجنبية لتلاميذ الصف الرابع الابتدائي. 


\section{Introduction}

Language is a vital tool for communication. It is not only a means of communicating thoughts and ideas, but it builds friendships, economic relationships and cultural ties. Listening, speaking, reading and writing are the four language skillsin need to be developed for successful communication. Reading has five pillars (phonemic awareness, phonics, fluency, vocabulary and comprehension). So, reading is the most important skill in language learning.

Despite its importance, reading is one of the most challenging areas in the educational system, because good readers should actively involve with the text, be aware of the processes they use to understand what they read (Küçükoğlu, 2013; Schwabe, McElvany, \&Trendtel, 2015). According to Al-Shboul, Ahmad, Nordin, and Rahman, (2013) pupils are afraid of making errors, worry about unknown vocabulary, unfamiliar topics and culture.

Trainin, Hiebert, and Wilson (2015) ; Price, Meisinger, Louwerse, and D'Mello (2016) and Jaca-Delfin (2017) divided types of reading into oral and silent reading. Rosseau ( 2012 , p.7) silent reading is "an inclassroom reading activity in which pupils are given a certain amount of time to silently read, self-selected material for pleasure or information as a way of cultivating a love of reading without assessment and skills work monitoring or instruction from the teacher".

Rasinski and Padak (2012) defined oral reading as the "ability to read text with accuracy, appropriate rate, and with good meaningful expression and appropriately phrased rendering of a written passage at an appropriately fluent speed (p.2)". According to Jaca-Delfin (2017) oral reading is the articulation of the sound and the letter combination of a language. During oral reading, students' reading difficulty can be 
identified and can be given proper intervention. Thus, oral reading is a useful tool in assessing one's reading ability.

Wilger (2008); Ali (2011); Stefanko( 2011); Shen (2013) and Khaleel (2016) divided oral reading skills into three components; rate (automaticity), accuracy and fluency. Grabe (2010) characterized L2 reading fluency as a complex cognitive process "involving rapid and accurate processing" ( $\mathrm{p}$. 72). In the same way, Kuhn, Schwanenflugel, and Meisinger (2010) confirmed that fluency is "skilled reading, underscores the significance of the ability to decode and comprehend at the same time and accepts the role of word recognition, rate and expression"(P.239).Grabe (2010) has characterized reading fluency as a complex cognitive process "involving rapid and accurate processing" (p. 72).

Therefore, oral reading fluency requires an achievement in the early years of the pupil's formal education. But few studies indicated the importance of phonological awareness for reading acquisition and oral reading fluency. For overcoming this challenge, pupils require explicit oral fluency training, which helps pupils to increase their performance by strengthening and makes an oral- language skill connection (Gibson, 2008 \& Ali, 2011). So, the present study used some phonological awareness strategies for developing some oral reading fluency.

One of the factors that affects oral reading performance is phonological awareness (PA) (Van den Boer, Van Bergen \&De Jong, 2014). Moreover, there is a significant relationship between phonological awareness and reading skills: this has been supported in many studies such as (Tunmer \& Rohl 1991; Cupples \& Iacono, 2000; Trehearne, Healy, Cantalini, \& Moore, 2003; Swanson, Rosston, Gerber \&Solari, 2008 \& Landon, 2017 ).

Phonological awareness (PA) refers to the ability to recognize individual letters and their corresponding sounds. It is the basis for decoding spoken words into phonemes (the smallest sound units of language). Also, 
decoding syllables (segments of speech that are uninterrupted by obstructions to airflow), onsets (the initial sound of a word), and rimes (the unit that follows the onset) (Elhassan, Crewther, \& Bavin, 2017).

PA is very important in the area of oral language that relates to the ability to think about the sounds in a word rather than just its meaning. It has two leading roles in reading: as an important predictor of reading achievement, and as a reading strategy ( Swanson, Rosston, Gerber \&Solari, 2008; Dahmer, 2010 \& Melby-Lervåg \& Lervåg , 2011). PA teaching serves to establish new knowledge in the pupils, with the sequence of normal development or typical learning as a guide (Schuele \& Boudreau , 2008).

Phonemic Awareness is one component of phonological awareness. It refers to knowledge of words at the level of individual sounds, how to segment, blend, or manipulate individual sounds in words. Phonic is the teaching of the alphabetic principle and the knowledge that different sounds of a language are represented by written symbols. Phonics is the last stage of phonemic development. This means that it is based on prior knowledge of phonology and phonemic awareness. Pupils should be taught the letters of the alphabet first, then consonants, vowels, blends (e.g., sh, ch), and phonics generalizations (Schuele \& Boudreau,2008\&Pilat\&Kilanowski-Press , 2011).

Phonological awareness is developed along a continuum of overlapping skills, beginning with the manipulation of larger units of sound and progressing to smaller unites of sound. Teachers must have a firm understanding of phonological awareness and how it affects reading development. Additionally, teachers must understand how to integrate phonological awareness instruction with classroom instruction. Progressing along the continuum, pupils move from segmenting sentences into individual words to segmenting words into individual syllables and then blending the segmented syllables back into words (Smith, 2018). 
There are a variety of tasks that strengthen preschool pupils' ability to manipulate syllables in a single word. These tasks include counting, identification, blending, segmenting, deletion, and substitution of syllables. Segmenting and blending words are two of the more difficult phonemic awareness abilities. They also promoted multiple opportunities for pupils to practise orally blending and segmenting words. An onset is the beginning consonant or consonant cluster in a syllable and the rime is the remaining vowel. Finally, manipulating the smallest units of sound and phonemes is a very difficult task for young children. However, the ability to successfully complete these tasks can predict a pupil's future success with reading acquisition (Anthony \& Francis, 2005).

\section{1- Context of the problem $\square$}

Despite the importance of improving oral reading skills at the primary stage, there are shortcomings in teaching English language oral reading fluency at most primary schools. It hasn't been given the attention from teachers. Pupils at this level make several errors in oral reading, such as omitting words, adding words or letters, switching some words or letters (Ali, $2011 \&$ Khaleel, 2016).

Through the researcher's experience as a teacher of English, she noticed the low level of the primary stage pupils in oral reading skills. They do not have the ability to read English correctly. They have common problems in oral reading skills. So, the researcher tried to make sure if the fourth year primary school pupils lack these skills or not.

\section{2- Statement of the Problem}

The problem of this study lies in the fourth year primary school pupils' low level in some EFL oral reading fluency.

\section{3- Questions of the Study $\square$}

This study attempted to answer the following questions;

1- What are EFL oral reading fluency skills required for fourth year primary school pupils? 
2- What are the features of phonological awareness strategies for developing some EFL oral reading fluency among fourth year primary school pupils?

3- How far phonological awareness strategies affect developing some EFL oral reading fluency skills among fourth year primary school?

\section{4- Hypotheses of the study}

\section{Hypothesis 1}

There is a statistically significant difference at the (0.01) level between the mean scores of the experimental group that of the control group in some EFL fluency skills in the post administration test of oral reading fluency skills in favor of the experimental group.

\section{Hypothesis 2}

There is a statistically significant difference at the (0.01) level between the mean scores of the experimental group in some EFL fluency skills on the pre- post administration of EFL oral reading fluency skills test in favor of the post administration.

\section{5- Purpose of the study}

This study aimed at investigating the effectiveness of using phonological awareness strategies for developing EFL oral reading fluency skills among primary school pupils.

\section{1- Review of literature}

\section{Reading fluency}

Oral reading fluency is the ability to read the words and text quickly, accurately, and with appropriate expression and automatically (National Reading Panel, 2000\&Rasinski, 2004 ). The Panel further included that fluency requires the rapid use of punctuation and the determination of where to place emphasis or where to pause to make sense of a text. 
Furthermore, Rasinski (2003) stated that "By focusing on oral reading fluency, students see that words are not the only part of the text that carry meaning. Meaning is also carried through the intonation, expression, phrasing, and pausing that are essential to fluent reading" (p. 34).

Kuhn, Schwanenflugel, and Meisinger (2010) presented reading fluency definitions; for example, fluency is accuracy and automaticity; emphasized accurate and automatic word recognition and related components, such as phonemic awareness and letter-sound correspondence. Also, fluency is prosody; this focuses on the role of phrasing and expressiveness. Finall, they concluded that fluency is a bridge to comprehension (p.237:239).

Although fluency has been a neglected factor in reading L2 (Wilger, 2008), many researchers asserted the strong relationship between reading fluency and comprehension (Klauda\&Guthrie,2008). For gaining meaning from the text, the student should obtain fluency and it is a domain for reading process. Also, the pupils have the ability of recognizing and reading the text fluently and accurately. In addition identifying, recognizing, and reading words automatically with expression helps the pupils to get meaning from the text (Hudson, Lane \& Pullen ,2005)

Klauda and Guthrie (2008) examined the relationship between the three levels of fluency (fluency at the word level, fluency at the syntactic level and fluency at the passage level) and comprehension. They asserted that word-level fluency is associated with comprehension at primary grades 1-3, whereas passage-level fluency is associated with comprehension at intermediate Grades 4-6. The results of this study supported that the various levels have different relationships to comprehension across different grade levels.

Fluency assessments must have some degree of reliability and validity. Users of the assessments must be assured that the results they obtain are reliable - that the results will provide consistent measures of 
fluency and will not vary because of imperfections in the assessment itself. Users must also be assured that the assessments are valid - that they actually measure reading fluency. The assessments themselves should resemble the ways in which reading fluency is defined ( Rasinski, 2004).

Helwa (2014) investigated the effects of using readers ' theatre based instruction on improving EFL oral reading fluency, reading comprehension and reading speed skills among preparatory stage pupils. The design combines both quantitative and qualitative modes of inquiry. The researcher used two groups: an experimental group and a control group. Results of the research revealed a statistically significant difference between the mean score of the experimental group and that of the control group in the post test of EFL oral reading fluency, reading comprehension and reading speed skills in favor of the experimental group. These results were attributed to using readers' theatre- based instruction.

Swain, Leader-Janssen and Conley (2017) examined the effectiveness of three fluency interventions ( repeated reading, audio listening passage preview and teacher modeled listening). By the end of the 7 weeks of intervention they compared to baseline, each intervention improved oral reading fluency. Teacher demonstrated listening passage preview resulted in the greatest fluency growth using R-CBM passages.

Therefore, oral reading fluency requires an achievement in the early years of the pupil's formal education. But few studies indicated the importance of phonological awareness for reading acquisition and oral reading fluency. For overcoming this challenge, pupils require explicit oral fluency training, which helps pupils to increase their performance by strengthening and making an oral- language skill connection (Gibson, 2008 \& Ali, 2011). So, the present study used phonological awareness strategies for developing oral reading fluency. 


\section{Phonological awareness (PA)}

PA is a term that refers to an individual awareness of the sound structure or phonological instruction of words. It has been connected to reading ability and reading process on the basis that the ability to interpret or sound out leads in general to the capacity to read. Clear awareness of phonological structure helps the pupils to draw a connection between spoken language and written symbols (Goldsworthy \& Pieretti, 2012 \& Gillon, 2017).

Almost all definitions of PA focused on the idea of the importance of phonological awareness to help learners improve their reading and spelling. Phonological awareness is a broad term that includes identifying and manipulating units of oral language such as words, syllables, onsets and rimes, and phonemes. This means that learners and teachers together work and play with the sounds of language at different levels (Mohammed, 2013).

O'Brien, Mohamed, Yussofand Ng (2018) examined syllable, rime and phoneme level awareness for bilingual children with differences in structure of their known languages in order to investigate any potential cross-language effects of their ethnic language on English reading. The study confirmed that Phonological awareness is critical for early reading acquisition across alphabetic as well as non-alphabetic languages.

To sum up, phonological awareness is very important for over all reading skills and reading fluency. The present study used three phonological awareness strategies for developing oral reading fluency (rhyming, alliteration and blending and segmentation)

\section{Phonological awareness strategies}

\section{1- Rhyming strategy}

Rhyming provides the pupils with an opportunity to begin developing an awareness of sounds and it is one of the early phases of phonological awareness. Rhyming allows the pupils to explore the rhythm 
of language. Another advantage of rhyming is enhancing the pupils' ability to express with some animation in their voice instead of just saying a statement in a monotone voice. Moreover, this strategy develops higher order thinking levels. In the first level (remembering and understanding), the pupils could know what a rhyming word is. In the second level (applying), the pupils could draw what rhymes with. The third level (analyzing), the pupils know how these two words are alike. In the final level (evaluating and creating), the pupils could create a sentence which includes a key vocabulary word used as a rhyming (Ellery, 2017).

\section{2- Alliteration Strategy}

The earliest aspect of phonological awareness is the ability to recognize rhyming and alliteration. So, Neaum(2017, p. 152)asserted that the pupils need the opportunity to "engage with rhymes, songs and poems to tune their ears into the sound of rhyme and alliteration". This opportunity to recognize and interact with rhymes, songs and poems and to engage in language play has a very benefit of drawing pupils' attentions of words.

Alliteration is an effective strategy to increase the pupils' attention to the sounds. Alliteration is the identification of the common first sounds of the words .Bryant and Goswami (2016) explained that the pupils can recognize alliteration long before going to school, this relate to success in learning to read. The progression of rhyming and alliteration affects on the pupils' ability of blending and segmentation, manipulation and identification. Thus, the developmental sequence seems to take this form. First, the pupils should begin with rhyming and alliteration, and then they are taught to learn to read and write. Then, at the same time they start to learn to read, the pupils start to isolate phoneme.

\section{3- Blending and segmentation strategy}

Segmentation is the ability to separate the component sounds of a word. In contrast, blending is the ability to combine the separated 
component sounds. Blending and segmentation are significantly related to each other, in single word reading, and to reading comprehension. Blending and segmentation supports the strong relationship between PA performance and reading achievement (Evans, 1998). Daly, Chafouleas, Persampieri, Bonfiglio, and LaFleur (2004) asserted the causal role of blending and segmenting in the development of reading proficiency.

Yeh and Connell (2008) confirmed that pupils who lack phoneme segmentation and blending skills exposed to be poor reader and there is a significance relationship between blending and segmentation strategy and reading comprehension. They supported an important conclusion: that the combination of phoneme segmentation, phoneme blending and letter-sound instruction is more effective in promoting phoneme segmentation skill than either an approach emphasizing rhyming or an approach emphasizing vocabulary instruction.

Vloedgraven and Verhoeven (2009) examined children's phonological awareness throughout the elementary school grades. Phonological awareness was assessed using five different sets of items that measured rhyming, phoneme identification, phoneme blending, phoneme segmentation, and phoneme deletion. A sample of 1405 children from kindergarten through fourth grade participated. Results showed phonological awareness is dimensional across different tasks and grades. In addition to some overlap between the item sets, those for rhyming, phoneme identification, and phoneme blending were easier than those for phoneme segmentation and phoneme deletion. The results lend support to the assumption that phonological awareness is a continuum of availability for phonological representations which can range from partial availability to full availability.

More importantly, Ellery (2017) demonstrated that blending and segmenting strategy effectively increased higher order thinking. When the pupil uses blending and segmenting, remembering and understanding 
(recall) level are increased by remembering the words in the sentences. The second level (applying) is increased by establishing syllable or sound he heard in the word. The third level (analyzing) is increased by saying the word slowly to knowing each sound or phoneme in the word. The final level (evaluating) this level is increased by investigating words by their syllables and how many letters are represented in highlighted syllable.

In summary, all previous studies asserted the importance of phonological awareness in reading and oral reading fluency especially in any alphabetical system. Depending on that, struggling in phonological awareness leads to difficulty in reading development. According to the continuum development of phonological awareness, pupils use blending and segmentation to split the word into its smallest units (phonemes). Phonological awareness strategies facilitate reading fluency in an easy way.

\section{1- Method}

\section{Participants of the Study}

The participants of the present study were selected from fourth year primary school pupils enrolled in AL Shaheed Mohamed Adel Rohmam School, in Menoufia Governorate during the second semester of the school year 2018/2019. The study participants $(N=60)$ included two intact classes: class $4 / 2$ was assigned as the experimental group $(\mathrm{N}=30)$ which was taught using some phonological awareness strategies (rhyming, alliteration and blending and segmentation) and class 4/1 was assigned as the control group $(\mathrm{N}=30)$ which was taught by traditional strategy as prescribed in the teacher's guide by the Ministry of Education.

\section{Instruments and materials of the Study $\square$}

The following instruments and materials were developed:

1- An EFL oral reading fluency checklist.

2- An EFL oral reading fluency Pre-Posttest. 
3- A teacher's guide that describes the steps to be followed when using the steps of phonological awareness strategies for developing some EFL oral reading fluency.

\section{Procedures of the Study}

These procedures were followed to fulfill the purpose of this study:

1- Identifying the some EFL oral reading fluency required for fourth year primary stage pupils through:

a) Reviewing literature, directives of the Ministry of Education, Pupils' Book, and previous studies related to EFL oral reading fluency.

b) Preparing a checklist of EFL oral reading fluency required for first year secondary stage pupils.

c) Submitting the list to a panel of jury members to verify its validity.

d) Modifying and setting the list in its final form in the light of the jury's suggestions.

2- Identifying the features of the phonological awareness strategies through:

a) Reviewing literature and previous studies related to phonological awareness.

b) Identifying steps of phonological awareness strategies.

c) Preparing a teacher's guide that describes in details how to use phonological awareness strategies for developing some EFL oral reading fluency.

3- Identifying the effect of using phonological awareness strategies on developing pupils' EFL oral reading fluency through:

a) Preparing a pre-post EF Loral reading fluency test. 
b) Submitting this test to a panel of jury members to verify its validity.

c) Estimating the validity and reliability of the pre-post oral reading fluency test.

d) Assigning a group of fourth year primary stage pupils as an experimental group and another as a control group.

e) Administering the pre EFL oral reading fluency test to the two groups as a pre-test.

f) Teaching the experimental group using some phonological awareness strategies.

g) Administering the EFL oral reading fluency test to the two groups.

h) Tabulating data of the study and conducting statistical analysis.

i) Interpreting the findings of the study.

j) Providing recommendations and suggestions for further research.

\section{Results of the study}

This study aimed at examining the effects of using phonological awareness strategies for developing some EFL oral reading fluency skills among primary school pupils. Statistical Package for Social Sciences (SPSS), version18 was used for analyzing the data.

\section{Results related to hypothesis (1)}

There is a statistically significant difference at the (0.01) level between the mean scores of the experimental group that of the control group in fluency skills in post administration test of oral reading fluency in favor of the experimental group. 
G. Gamal \& Dr. E. Mohamed \& Dr. M. Mohamed Using Phonological Awareness Strategies for Developing

Table (1) Findings of t-test of the post EFL oral reading fluency in each micro-skill between the experimental group and the control group.

\begin{tabular}{|c|c|c|c|c|c|c|c|c|c|}
\hline $\begin{array}{l}\text { Macro } \\
\text { - skills }\end{array}$ & Micro skills & Group & NO. & Mean & $\begin{array}{c}\text { Std. } \\
\text { Deviation }\end{array}$ & t-value & DF & $\begin{array}{c}\alpha \\
\text { Sig }\end{array}$ & $\eta 2$ \\
\hline \multirow{4}{*}{ 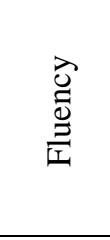 } & \multirow{2}{*}{ Reading simple sentences. } & Experimental & 30 & 3.53 & 0.57 & \multirow{2}{*}{8.43} & \multirow{2}{*}{58} & \multirow{2}{*}{0.01} & \multirow{2}{*}{0.55} \\
\hline & & Control & 30 & 1.93 & 0.87 & & & & \\
\hline & \multirow{2}{*}{$\begin{array}{l}\text { Reading and answering } \\
\text { the simple questions. }\end{array}$} & Experimental & 30 & 2.77 & 0.68 & \multirow{2}{*}{2.75} & \multirow{2}{*}{58} & \multirow{2}{*}{0.01} & \multirow{2}{*}{0.12} \\
\hline & & Control & 30 & 2.23 & 0.82 & & & & \\
\hline \multirow{2}{*}{\multicolumn{2}{|c|}{ The overall fluency }} & Experimental & 30 & 6.30 & 0.84 & \multirow{2}{*}{8.86} & \multirow{2}{*}{58} & \multirow{2}{*}{0.01} & \multirow{2}{*}{0.58} \\
\hline & & Control & 30 & 4.17 & 1.02 & & & & \\
\hline
\end{tabular}

Table (1) shows that there is a statistically significant difference between the mean scores of the experimental group and those of the control group in fluency skills in post test in favor of the experimental group. T-value is (8.86) which is significant at the (0.01) level. The effect size is high as $\mathrm{y} 2$ is greater than 0.14 .

\section{Results related to hypothesis (2)}

There is a statistically significant difference at the (0.01) level between the mean scores of the experimental group in EFL fluency skills on the pre- post administration of EFL oral reading fluency test in favor of the post administration.

Table (2) Findings of t-test of the EFL oral reading fluency post administration in each sub skill of the experimental group

\begin{tabular}{|c|c|c|c|c|c|c|c|c|c|}
\hline $\begin{array}{c}\text { Macro - } \\
\text { skills }\end{array}$ & Micro skills & Group & NO. & Mean & $\begin{array}{c}\text { Std. } \\
\text { Deviation }\end{array}$ & t-value & DF & $\begin{array}{r}\text { A } \\
\text { Sig }\end{array}$ & $\eta 2$ \\
\hline \multirow{4}{*}{ 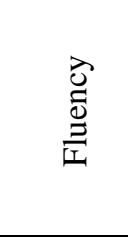 } & \multirow{2}{*}{ Reading simple sentences. } & Pre & 30 & 1.73 & 0.57 & \multirow{2}{*}{11.12} & \multirow{2}{*}{29} & \multirow{2}{*}{0.01} & \multirow{2}{*}{0.81} \\
\hline & & Post & 30 & 3.53 & 0.78 & & & & \\
\hline & \multirow{2}{*}{$\begin{array}{l}\text { Reading and answering } \\
\text { the simple questions. }\end{array}$} & Pre & 30 & 1.87 & 0.68 & \multirow{2}{*}{4.64} & \multirow{2}{*}{29} & \multirow{2}{*}{0.01} & \multirow{2}{*}{0.43} \\
\hline & & Post & 30 & 2.77 & 0.73 & & & & \\
\hline \multirow{2}{*}{\multicolumn{2}{|c|}{ The overall fluency }} & Pre & 30 & 3.60 & 0.84 & \multirow{2}{*}{12.25} & \multirow{2}{*}{29} & \multirow{2}{*}{0.01} & \multirow{2}{*}{0.84} \\
\hline & & Post & 30 & 6.30 & 1.10 & & & & \\
\hline
\end{tabular}


Table (2) shows that there is a statistically significant difference between the mean scores of the experimental group on the pre-post administration of EFL oral reading fluency test in favor of the post administration. T-value is (12.25) which is significant at the (0.01) level. The effect size is high as $\mathrm{\eta} 2$ is greater than 0.14 .

\section{Discussion and Interpretation of the Results}

The purpose of the present study was to develop some EFL oral reading fluency skills through using phonological awareness strategies. The findings of the present study indicated that phonological awareness strategy had a positive effect on the participant's experimental oral reading fluency. These results are consistent with the previous studies which proved the great contribution of phonological awareness strategies in developing EFL oral reading skills, such as (Anthony \& Francis, 2005 ; Dahmer, 2010; Melby-Lervåg \& Lervåg , 2011; Güldenoğlu ,2016 \& Landon, 2017 )

On the other hand, the studies of Christodoulou et al. (2014) and Kilpatrick (2018) asserted the strong relationship between PA and reading fluency through phonemic level. Subsequently, the present study proved the effectiveness of using some phonological awareness strategies for developing EFL oral reading fluency among fourth year primary school pupils. But, blending and segmentation and rhyming strategies showed significant gains in oral reading skills, compared to alliteration strategy

\section{Conclusions}

Before implementing the strategies, there seemed to be a lack in some EFLoral reading fluency among the study participants. Hence, there was a need for developing EFL oral reading fluency among them. Thus, the present study used phonological awareness strategies which aimed at developing some EFL oral reading fluency.

In the light of the results of the study, it can be concluded that the EFL oral reading fluency were developed among 4th primary school 
pupils by using phonological awareness strategies. Consequently, it can be concluded that PA strategies were found to be effective on developing some EFL oral reading fluency.

\section{Recommendations of the study $\square$}

Based on the results and findings of the present study, the following recommendations should be taken in consideration:

1- EFL teachers should pay attention to the development of their pupils' oral reading fluency at the primary stage because the pupils in this stages build the basis of correct pronunciation and the beginning of decoding skills in order to be successful readers .

2- EFL educators should become more aware of the necessity of teaching EFL oral reading fluency.

3- EFL educators should assess the pupils' oral reading fluency because multiple assessments provide the teachers with a degree of accountability and precision for their teaching.

4- Phonological awareness strategies should be implemented in teaching EFL oral reading fluency to pupils at the primary stage.

\section{Suggestions for Further Research $\square$}

In the light of the findings of the present study, the following topics are suggested for further research:

1- Investigating the effect of the phonological awareness strategies on developing other language skills as listening, speaking and writing.

2- Identifying the impact of phonological awareness strategies on improving EFL oral reading fluency among learners at different level of the primary stage.

3- Identifying the challenge that affect pupils' oral reading fluency.

4- Comparing the effectiveness of other strategies on the EFL oral reading skills among pupils at different educational levels. 


\section{References}

Al Jaffall, F. M. (2014). The effect of repeated reading strategy on oral reading fluency of a fourth grade student with reading difficulties. These.United Arab Emirates University.College of Education.

Ali, S.M.A. (2011).Using blended learning for improving six primary pupils oral reading skills. Journal of Faculty of education .AinShams University. 1(17), 69-110.

Al-Shboul, M. M., Ahmad, I. S., Nordin, M. S., \&Rahman, Z. A. (2013). Foreign Language Reading Anxiety in a Jordanian EFL Context: A Qualitative Study. English Language Teaching, 6(6), 38-56.

Anthony, J. L., \& Francis, D. J. (2005).Development of phonological awareness. Current Directions in Psychological Science, 14(5), 255-259.

Bryant, P., \& Goswami, U. (2016).Phonological skills and learning to read. Routledge.

Christodoulou, J. A., Del Tufo, S. N., Lymberis, J., Saxler, P. K., Ghosh, S. S., Triantafyllou, C., \&Gabrieli, J. D. E. (2014). Brain bases of reading fluency in typical reading and impaired fluency in dyslexia. PLoS ONE, 9(7), e100552. doi:10.1371/journal.pone.0100552

Cupples, L., \&Iacono, T. (2000). Phonological Awareness and Oral Reading Skill in Children With Down Syndrome. Journal of Speech, Language \& Hearing Research ,43(3), 595-608.

Dahmer, M. C. (2010). Phonological awareness in the kindergarten classroom: How do teachers perceive this essential link from oral communication to reading skill development. Dissertation. The Faculty of the School of Education. Liberty University. 
Daly, E. J., Chafouleas, S. M., Persampieri, M., Bonfiglio, C. M., \& La Fleur, K. (2004). Teaching phoneme segmenting and blending as critical early literacy skills: An experimental analysis of minimal textual repertoires. Journal of Behavioral Education, 13(3), 165-178.

Elhassan, Z., Crewther, S. G., \& Bavin, E. L. (2017). The contribution of phonological awareness to reading fluency and its individual subskills in readers aged 9-to 12-years. Frontiers in psychology, 8, 533.

Ellery, V. (2017).Creating strategic readers: Techniques for supporting rigorous literacy instruction (Vol. 3). Shell Education.

Evans, K. D. (1998). The effect of training segmentation and blending on decoding skills .Doctoral dissertation, California State University, Fresno.

Gibson, S. (2008). Reading aloud: A useful learning tool? English Language Teaching Journal,62, 29-36. https://academic.oup.com/eltj/article-abstract/62/1/29/416435.

Gillon, G. T. (2017). Phonological awareness: From research to practice .Guilford Publications.

Goldsworthy, C., \&Pieretti, R. (2012).Sourcebook of phonological awareness activities (Vol. 4). Nelson Education

Gottardo, A., Pasquarella, A., Chen, X., \& Ramirez, G. (2016). The impact of language on the relationships between phonological awareness and word reading in different orthographies: A test of the psycholinguistic grain size theory in bilinguals. Applied Psycholinguistics, 37(5), 1083-1115.

Grabe, W. (2010).Fluency in Reading--Thirty-Five Years Later. Reading in a foreign language, 22(1), 71-83.

Helwa, H. S. A. H. A. (2014). The Effects of Using Reader's TheatreBased Instruction on Improving EFL Oral Reading Fluency, Reading Comprehension and Reading Speed Skills among Preparatory Stage Pupils. Journal of Arabic Studies in Education and Psychology, (53), 291-334. 
Hudson, R., Lane, H., \& Pullen, P. (2005). Reading fluency assessment and instruction: What, why and how? The Reading Teacher, 58(8), 702-714.

Jaca-Delfin, C. ( 2017 ). Cebuano and English Oral Reading Fluency Among Beginning Readers. International Journal of Linguistics and Education.2(1), 1-5. doi: 10.11648/j.ijle.20170201.11

Khaleel, H. A. A. (2016). A blended learning program to improve the oral reading skills of the middle-stage pupils in iraq republic. Doctoral dissertation. Mansoura University. Egypt.

Klauda, S. L., \& Guthrie, J. (2008).Relationships of Three Components of Reading Fluency to Reading Comprehension. Journal of Educational Psychology, 100(2), 310-321.

Kilpatrick, D. A. (2018).Equipped for Reading Success: A Comprehensive, Step-by-step Program for Developing Phoneme Awareness and Fluent Word Recognition. Casey \& Kirsch Publishers.

Küçükoğlu, H. (2013). Improving reading skills through effective reading strategies. Procedia-Social and Behavioral Sciences, 70, 709-714.

Kuhn, M. R., Schwanenflugel, P. J., \& Meisinger, E. B. (2010).Aligning theory and assessment of reading fluency: Automaticity, prosody, and definitions of fluency. Reading Research Quarterly, 45(2), 230-251.

Landon, L. L. (2017). English Word-Level Decoding and Oral Language Factors as Predictors of Third and Fifth Grade English Language Learners' Reading Comprehension Performance. Doctoral dissertation, The George Washington University.

Melby-Lervåg, M., \& Lervåg, A. (2011). Cross-linguistic transfer of oral language, decoding, phonological awareness and reading comprehension: A meta-analysis of the correlational evidence. Journal of Research in Reading, 34(1), 114-135. 
Mohammed, F. O. (2013). The use of phonological awareness skills in teaching phonetics and phonology for university students. IOSR Journal Of Humanities And Social Science (IOSR-JHSS) Volume, 19, 101-116.

National Reading Panel (2000). Report of the National Reading Panel: Teaching Children to Read. An Evidence-Based Assessment of the Scientific Research Literature on Reading and its Implications for Reading Instruction.Washington, DC: U.S.

Neaum, S. (2017). What Comes Before Phonics?.Learning Matters.

Nevills, P., \& Wolfe, P. (Eds.). (2009). Building the reading brain, PreK-3. Corwin Press.

O’Brien, B. A., Mohamed, M. B. H., Yussof, N. T., \& Ng, S. C. (2018).The phonological awareness relation to early reading in English for three groups of simultaneous bilingual children. Reading and Writing, 1-29.

Pilat C., Kilanowski-Press L. (2011). Phonological Awareness. In: Goldstein S., Naglieri J.A. (eds) Encyclopedia of Child Behavior and Development. Springer, Boston, MA.

Price, K. W., Meisinger, E. B., Louwerse, M. M., \&D’Mello, S. (2016). The Contributions of Oral and Silent Reading Fluency to Reading Comprehension. Reading Psychology, 37(2), 167-201. doi:10.1080/02702711.2015.1025118

Rasinski, T. (2004).Assessing reading fluency.Pacific Resources for Education and Learning, 1-25.Retrieved from: https://eric.ed.gov/?id=ED483166.

Rasinski, T. V. (2003). The fluent reader: Oral reading strategies for building word recognition, fluency, and comprehension. New York: Scholastic Professional Books. 
Rasinski, T. V., \& Padak, N. D. (2012). From phonics to fluency: Effective teaching of decoding and reading fluency in the elementary school. Pearson Higher Ed.

Rosseau, a. s. (2012).Effects of silent reading on intermediate students' reading growth. M.A thesis.

Schuele, C. M., \& Boudreau, D. (2008). Phonological awareness intervention: Beyond the basics. Language, Speech, and Hearing Services in Schools.

Schwabe, F., McElvany, N., \&Trendtel, M. (2015).Reading skills of students in different school tracks: Systematic (dis) advantages based on item formats in large scale assessments. ZeitschriftfürErziehungswissenschaft, 18(4), 781-801.

Schwanenflugel, P. J., Meisinger, E. B., Wisenbaker, J. M., Kuhn, M. R., Strauss, G. P., \& Morris, R. D. (2006). Becoming a fluent and automatic reader in the early elementary school years. Reading research quarterly, 41(4), 496-522.

Shen, Y. (2013). Balancing accuracy and fluency in English classroom teaching to improve Chinese non-English majors' oral English ability. Theory and Practice in Language Studies, 3(5), 816.

Smith, S. A. (2018). Paving the Path to Reading Success: Phonological Awareness in Pre-Kindergarten. Lamar University-Beaumont.

Stefanko B. (2011). Oral Reading. In: Goldstein S., Naglieri J.A. (eds) Encyclopedia of Child Behavior and Development. Springer, Boston, MA.

Swain, K. D., Leader-Janssen, E. M., \& Conley, P. (2017). Effects of repeated reading and listening passage preview on oral reading fluency. Reading Improvement, 54(3), 105-111 
Swanson, H. L., Rosston, K., Gerber, M., \&Solari, E. (2008). Influence of oral language and phonological awareness on children's bilingual reading. Journal of School Psychology, 46(4), 413-429.

Trainin, G., Hiebert, E. H., \& Wilson, K. M. (2015). A comparison of reading rates, comprehension, and stamina in oral and silent reading of fourth-grade students. Reading Psychology, 36(7), 595-626

Trehearne, M., Healy, L. H., Cantalini, M., \& Moore, J. L. (2003).Comprehensive literacy resource for kindergarten teachers. Vernon Hills, IL: ETA/Cuisenaire.

Tunmer W.E.\&Rohl M. (1991) Phonological awareness and reading acquisition. Phonological awareness in reading. The evolution of current perspective. D. J. Sawyer B.J. Fox (éds.), New York : Springer-Verlag, pp. 1-30.

Van den Boer, M., Van Bergen, E., \& De Jong, P. F. (2014). Underlying skills of oral and silent reading.Journal of experimental child psychology, 128, 138-151.

Vloedgraven, J., \&Verhoeven, L. (2009). The nature of phonological awareness throughout the elementary grades: An item response theory perspective. Learning and Individual Differences, 19(2), 161-169.

Wilger, M. P. (2008). Reading fluency: A bridge from decoding to comprehension research brief. Ottawa: Outoskills International Inc.

Yeh, S. S., \& Connell, D. B. (2008).Effects of rhyming, vocabulary and phonemic awareness instruction on phoneme awareness.Journal Of Research In Reading, 31(2), 243-256. doi:10.1111/j.14679817.2007.00353 